\title{
Antimicrobial Efficacy of Herbal and Chlorhexidine Mouth rinse - A systematic review
}

\author{
Dr. N. Nagappan ${ }^{1}$, Dr. Joseph John ${ }^{2}$ \\ ${ }^{1,2}$ (Dept of Public Health Dentistry, Saveetha University, India)
}

\begin{abstract}
Objectives: To evaluate the antimicrobial efficacy of herbal and chlorhexidine mouth rinses against Streptococcus mutans. Search strategy: The following electronic retrieval systems and databases were selected for identification of studies. The Cochrane central register of controlled trials, Pub Med, LILACS / BBO, MEDLINE, SCIENCE DIRECT. Selection criteria: Studies with both herbal and chlorhexidine mouth rinse with outcome measure like zone of inhibition and minimum inhibitory concentration were included for this review. Conclusion: This review demonstrates that, compared to herbal mouth rinse, chlorhexidine mouth rinse provided better results in its antimicrobial efficacy against streptococcus mutans. Further research could study the antimicrobial efficacy of herbal mouth rinse in greater depth and in vivo clinical testing is essential to confirm the in vitro results.
\end{abstract}

KEY WORDS: Herbal mouth rinse, antimicrobial activity, streptococcus mutans, chlorhexidine mouth rinse.

\section{Introduction}

Mouth rinses have been used for centuries for medicinal and cosmetic purposes, but it is only in recent years that the rationale behind the use of chemical ingredients has been subject to scientific research and clinical trials.$^{[1]}$ Today's dentists are practicing in an era where the patients are more concerned about both their oral health and their overall medical wellbeing. Thus, in the midst of growing evidence of the connection between oral health and whole body health, herbal medicines with their 'naturally occurring' active ingredients offer a gentle and enduring way for restoration of health by the most trustworthy and least harmful way. ${ }^{[2]}$

Herbal medicine is both promotive and preventive in its approach. It is a comprehensive system, which uses various remedies derived from plants and their extracts to treat disorders and to maintain good health. Natural herbs like triphala, tulsi patra, jyestiamadh, neem, clove oil, pudina, ajwain and many more used either as whole single herb or in combination have been scientifically proven to be safe and effective medicine against various oral health problems like bleeding gums, halitosis, mouth ulcers and preventing tooth decay. The major strength of these natural herbs is that their use has not been reported with any side-effects till date. ${ }^{[2]}$

Apart from this, all herbal mouth rinses do not contain alcohol and/or sugar, two of the most common ingredients found in most other over-the-counter products. The problem of these ingredients is that the microorganisms that cause bad breath and halitosis love to feed on these ingredients, and release byproducts that cause halitosis. ${ }^{[2]}$ Thus, by use of a herbal mouth rinse, we can avoid these ingredients, which itself is one step forward towards better oral hygiene and better health.

Chlorhexidine, a cationic bisbiguanide with a very broad antimicrobial spectrum is the most widely used over the counter mouth rinse. It is used as an adjunct to mechanical cleaning procedures as well as used alone. Its effectiveness was also shown for control of gingivitis in long-term studies. The major advantage of chlorhexidine over most other compounds lies in its substantivity. It binds to soft and hard tissues in the mouth, enabling it to act over a long period after application of a formulation. ${ }^{[1]}$ However, chlorhexidine has several side effects, such as staining and taste alteration, which limit its long term use. ${ }^{[3]}$ Therefore, chlorhexidine is used as a positive control in many clinical trials of new mouth rinse formulations and is considered the gold standard. ${ }^{[1]}$

Systematic reviews have rapidly gained an important place in aiding clinical decision making in medicine, although dentistry has been somewhat slower to adopt this approach. The objective of a systematic review is to provide a comprehensive and contemporary appraisal of research using transparent methods while aiming to minimize bias. If such conditions are met, there should be greater confidence in the conclusions of the review than in other summaries of clinical evidence. ${ }^{[4]}$ To our knowledge, there is no systematic review available that has evaluated comparisons of herbal mouth rinse to a chlorhexidine mouth rinse. The aim of this review is to evaluate the efficacy of herbal and chlorhexidine mouth rinse against Streptococcus mutans. 
II. Methods

Criteria for considering studies for this review

We included studies which tested the antimicrobial efficacy of herbal and chlorhexidine mouth rinses against Streptococcus mutans. The inclusion criteria for the articles in this review are

1. In-vitro studies

2. Studies relevant to the objective of this review.

3. Language of publication comprehensible by the reviewer

4. Studies with outcome parameters like zone of inhibition and minimum inhibitory concentration were included for this review.

The included articles were reviewed in depth and excluded according to the following criteria:

1. Clinical trials

2. Animal studies

3. Review articles, letter to editors (not containing primary data).

Types of mouth rinses included:

Test mouth rinse - Herbal mouth rinse

Control mouth rinse - Chlorhexidine mouth rinse

\section{Types of interventions}

In all studies herbal and chlorhexidine mouth rinse were used. The antimicrobial activity of herbal and chlorhexidine mouth rinse was measured by diameter of zone of inhibition. The zone of inhibition was determined by Standard Diffusion method. The minimum inhibitory concentration was also determined by Dilution method.

\section{Types of outcome measures}

The primary outcome was to see the antimicrobial efficacy of herbal and chlorhexidine mouth rinse against Streptococcus mutans. Outcome parameters like difference in diameter of zone of inhibition and minimum inhibitory concentration were assessed.

\section{Search methods for identification of studies}

A comprehensive literature search of the following databases were done which included studies of The Cochrane database of systematic reviews, Pub Med, LILACS / BBO, MEDLINE, SCIENCE DIRECT (Until June 2012). We also searched websites of product manufacturers, as well as Google scholar.

\section{Electronic search key words}

Materials: mouth rinse, mouthwash, herbal extract, herbal mouth rinse, chlorhexidine mouth rinse.

Measures: Antimicrobial efficacy

Variables of interest:

- Zone of inhibition,

- Minimum inhibitory concentration

Data collection and analysis

Study selection

The review author independently carried out the selection of papers on the basis of the title, keywords and abstract, and the decision about eligibility.

\section{Data extraction}

Data was extracted independently by the author using a data extraction form. Characteristics relating to material that were extracted included: zone of inhibition and minimum inhibitory concentration.

\section{Description of the studies}

\section{Results}

The review included six studies, which assessed the antimicrobial efficacy of herbal and chlorhexidine mouth rinse against Streptococcus mutans. (Pooja Agarwal et al 2010, Dalinsali Z et al 2011, Vijaya Hegde et al 2011, Hasanali et al 2012, Fereshten et al 2012, Mansour Amin et al 2012). All of the studies were conducted invitro and antimicrobial efficacy against Streptococcus mutans was assessed.

Five of the six included studies measured zone of inhibition (Pooja Agarwal et al 2010, Dalinsali Z et al 2011, Vijaya Hegde et al 2011, Hasanali et al 2012, Fereshten et al 2012) and two of the six included studies 
measured minimum inhibitory concentration (Amin et al 2012, Fereshten et al 2012) as outcome measure. Two of the included studies measured both zone of inhibition and minimum inhibitory concentration (Fereshten et al 2012, Hasanali et al 2012).

In all the studies reviewed, herbal mouth rinse (Test group) was compared to chlorhexidine (Control group). The antimicrobial activity of herbal and chlorhexidine mouth rinse was measured by diameter of zone of inhibition. The zone of inhibition was determined by Standard Diffusion method. The minimum inhibitory concentration was determined by Dilution method. The six studies included in this review were of evidence level III (In-vitro studies).

\section{Effects of intervention}

For all the three studies which measured the zone of inhibition by mean and standard deviation (Dalinsali Z et al 2011, Fereshten et al 2012 and Hasanali et al 2012) chlorhexidine mouth rinse had a comparatively greater zone of inhibition than herbal mouth rinse and the difference was found to be significant statistically, and for the two studies which measured the zone of inhibition by millimeter (Pooja Agarwal et al 2010, Vijaya Hegde et al 2011) chlorhexidine mouth rinse had a greater zone of inhibition than herbal mouth rinse. For all the two studies which measured minimum inhibitory concentration (Fereshten et al 2012, Mansour Amin et al 2012) garlic juice had a minimum inhibitory concentration.

\section{Discussion}

In this review the antimicrobial efficacy of herbal and chlorhexidine mouth rinse was measured by zone of inhibition and minimum inhibitory concentration. An antimicrobial effect of herbal extracts has been widely studied but little research has been done to assess the effect of herbal extracts on streptococcus mutans. This review reveals that limited published literature exists assessing the antimicrobial efficacy of herbal and chlorhexidine mouth rinse against Streptococcus mutans. The data was subjected to meta-analysis, forest plot drawn showed that chlorhexidine mouth rinse was found to be effective when compared to a test group. All the three studies showed significant improvement in chlorhexidine mouth rinse (Dalinsali Z et al 2011, Hasanali et al 2012, Fereshten et al 2012). The two studies (Pooja Agarwal et al 2010, Vijaya Hegde et al 2011) which measured the zone of inhibition by millimeter shows the improvement in chlorhexidine mouth rinse. The two studies ( Fereshten et al 2012, Mansour Amin et al 2012) which measured the Minimum inhibitory concentration shows the improvement in garlic juice extract. To the best of our knowledge, as few studies have been done on antimicrobial effects of herbal products against oral pathogens, it is better that the effect of herbal extracts on other oral bacteria that have cariogenic activity be studied. Because of the antimicrobial effects of some herbal extracts, which have minimal side effects in comparisons with chemical drugs, more in vivo and in vitro investigations on the efficacy of herbal extracts on oral microbial flora should be studied.

\section{Figure 1: Search strategy}

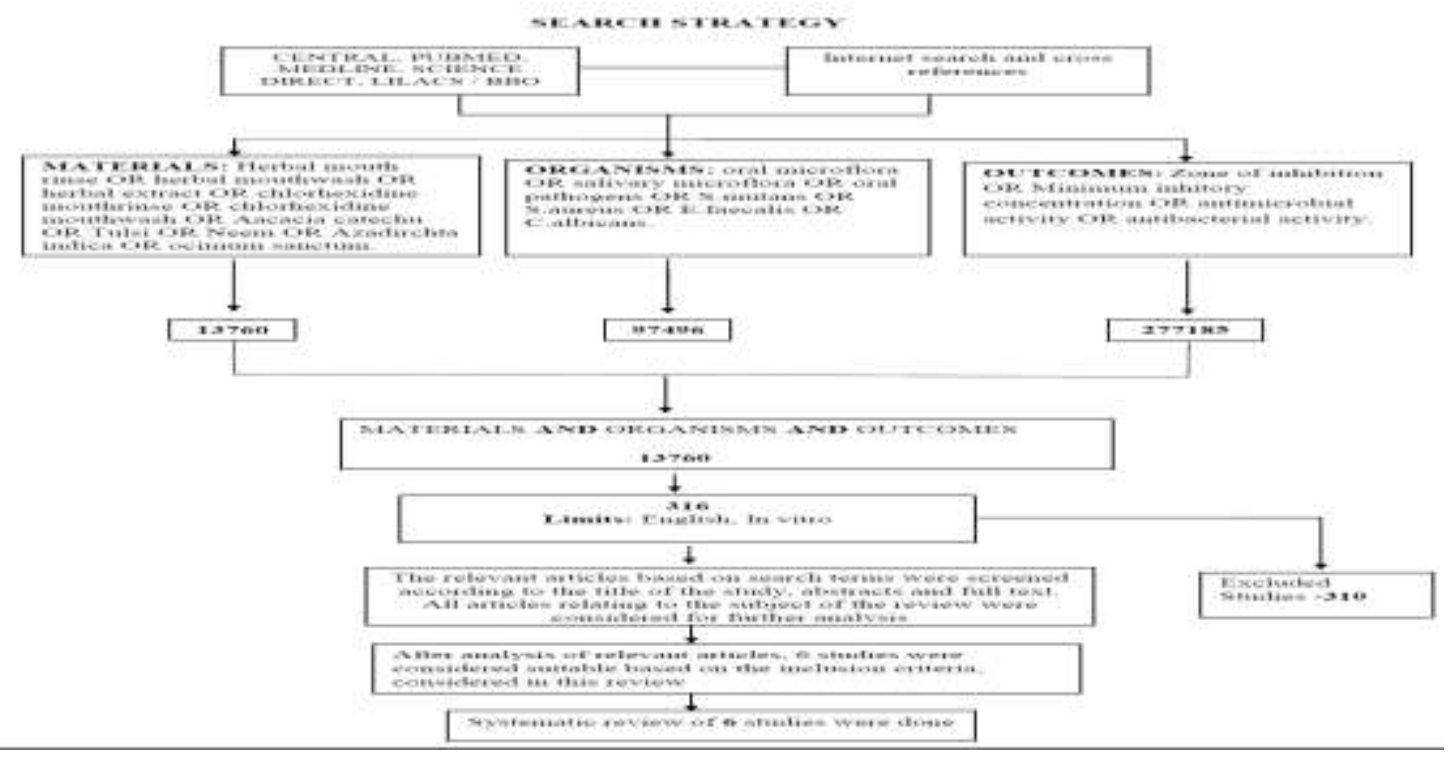

Www.iosrjournals.org 
Table 1: Characteristics of studies

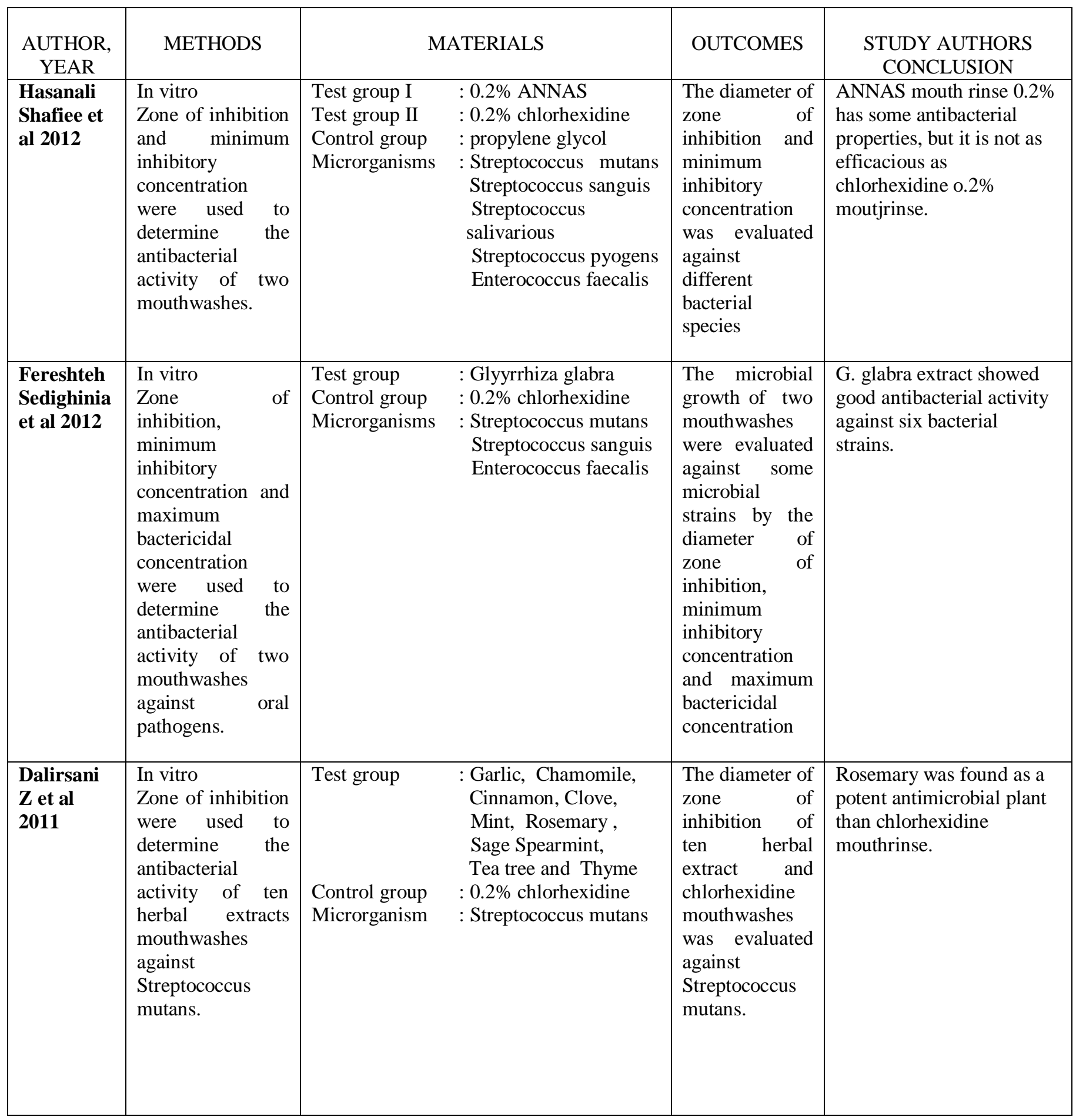


Antimicrobial Efficacy of Herbal and Chlorhexidine Mouth rinse -

\begin{tabular}{|c|c|c|c|c|c|}
\hline $\begin{array}{l}\text { Pooja } \\
\text { Agarwal et } \\
\text { al } 2010\end{array}$ & $\begin{array}{l}\text { In vitro } \\
\text { Zone of inhibition } \\
\text { were used to } \\
\text { determine the } \\
\text { antibacterial } \\
\text { activity of Tulsi } \\
\text { extract against } \\
\text { Streptococcus } \\
\text { mutans }\end{array}$ & $\begin{array}{l}\text { Test group } \\
\text { sanctum) } \\
\text { Control group } \\
\text { Microrganism }\end{array}$ & $\begin{array}{l}\text { : Tulsi (ocimum } \\
: 0.2 \% \text { chlorhexidine } \\
: \text { Streptococcus mutans }\end{array}$ & $\begin{array}{l}\text { The diameter of } \\
\text { zone of } \\
\text { inhibition of } \\
\text { tulsi (ocimum } \\
\text { sactum) herbal } \\
\text { extract and } \\
\text { chlorhexidine } \\
\text { mouthwashes } \\
\text { was evaluated } \\
\text { against } \\
\text { Streptococcus } \\
\text { mutans. }\end{array}$ & $\begin{array}{l}\text { Tulsi extract demonstrated } \\
\text { an antimicrobial property } \\
\text { againt streptococcus } \\
\text { mutans. }\end{array}$ \\
\hline $\begin{array}{l}\text { Mansour } \\
\text { Amin et al } \\
2012\end{array}$ & $\begin{array}{l}\text { In vitro } \\
\text { Zone of inhibition } \\
\text { were used to } \\
\text { determine the } \\
\text { antibacterial } \\
\text { activity of ten } \\
\text { herbal extracts } \\
\text { mouthwashes } \\
\text { against oral } \\
\text { pathogens. }\end{array}$ & $\begin{array}{l}\text { Test group } \\
\text { Control group } \\
\text { Microrganisms }\end{array}$ & $\begin{array}{l}\text { : Garlic juice } \\
: 0.2 \% \text { chlorhexidine } \\
: \text { Streptococcus mutans } \\
\text { Streptococcus sanguis } \\
\text { Streptococcus salivaris } \\
\text { Lactobacillus casei }\end{array}$ & $\begin{array}{l}\text { The minimum } \\
\text { inhibitory } \\
\text { concentration } \\
\text { was evaluated } \\
\text { for both control } \\
\text { and test } \\
\text { mouthrinses } \\
\text { against some } \\
\text { bacterial } \\
\text { strains. }\end{array}$ & $\begin{array}{l}\text { The efficacy of garlic juice } \\
\text { was higher than } \\
\text { Chlorhexidine against } \\
\text { target bacteria and could } \\
\text { be used as an effective } \\
\text { mouthwash, but its side } \\
\text { effects need to be } \\
\text { investigated. }\end{array}$ \\
\hline $\begin{array}{l}\text { Vijaya } \\
\text { Hegde et } \\
\text { al } 2011\end{array}$ & $\begin{array}{l}\text { In vitro } \\
\text { Zone of inhibition } \\
\text { were used to } \\
\text { determine the } \\
\text { antibacterial } \\
\text { activity of triphala } \\
\text { churna herbal } \\
\text { extracts and } \\
\text { chlorhexidine } \\
\text { mouthwash } \\
\text { against } \\
\text { Streptococcus } \\
\text { mutans. }\end{array}$ & $\begin{array}{l}\text { Test group } \\
\text { Control group } \\
\text { Microrganism }\end{array}$ & $\begin{array}{l}\text { : Triphala churna } \\
: 0.2 \% \text { chlorhexidine } \\
: \text { Streptococcus mutans }\end{array}$ & $\begin{array}{l}\text { The diameter of } \\
\text { zone of } \\
\text { inhibition of } \\
\text { triphala churna } \\
\text { herbal extract } \\
\text { and } \\
\text { chlorhexidine } \\
\text { mouthwash } \\
\text { was evaluated } \\
\text { against } \\
\text { Streptococcus } \\
\text { mutans. }\end{array}$ & $\begin{array}{l}\text { Triphala ,a ayurvedic } \\
\text { product can be used as a } \\
\text { mouthwash for a longer } \\
\text { period of time, without any } \\
\text { side effects. }\end{array}$ \\
\hline
\end{tabular}

DATA AND ANALYSIS

Table 2. Influential analysis of Zone of inhibition (Random effects model)

\begin{tabular}{|c|c|c|c|}
\hline Study & $\begin{array}{c}\text { Standardised mean } \\
\text { difference }\end{array}$ & $\begin{array}{c}\text { Confidence } \\
\text { Interval }\end{array}$ & $\begin{array}{c}\text { \% Weight } \\
\text { (Random) }\end{array}$ \\
\hline Hasanali 2012 & 1.550 & $-0.685-3.785$ & 28.76 \\
\hline Fereshteh 2012 & 0.514 & $-1.478-2.507$ & 36.21 \\
\hline Z.Dalirsani 2011 & 0.738 & $-1.288-2.763$ & 35.03 \\
\hline
\end{tabular}


Number of trials combined

Pooled estimates:

Standardised mean difference

95\% Confidence interval

Test for overall effect, $\mathrm{Z}$

$\mathrm{p}$ - value

$\begin{array}{ll}- & 3 \\ - & 0.891 \\ - & -0.308-2.089 \\ - & 1.456 \\ - & 0.145\end{array}$

Fig 2: Zone of inhibition - comparison Forest Plot

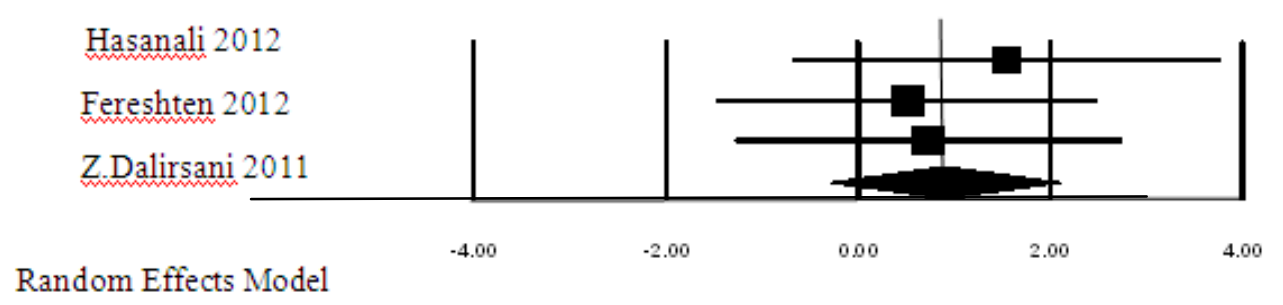

The random effects model pooled estimates are to the right side of the perpendicular line to show that interventions are effective regarding the studies analysed in this systematic review. The vertical line extending from the random effects model represents the Standardised mean difference 0.891 .

\section{Conclusion}

This review demonstrates that, compared to herbal mouth rinse, chlorhexidine mouth rinse provided better results in its antimicrobial efficacy against Streptococcus mutans. Further research could study the antimicrobial efficacy of herbal mouth rinse in greater depth and in vivo clinical testing is essential to confirm the in vitro results.

\section{References}

[1.] Van Leeumen M.P.C, Slot D.E and Van Der Weijden. Essential oils compared to chlorhexidine with respect to plaque and parameters of gingival inflammation: A systematic Review. Journal of Periodontology 2011; 82(2); 174-194.

[2.] Ranjan Malhotra, Vishakha Grover, Anoop Kapoor, Divya Saxena. Comparison of the effectiveness of a commercially available herbal mouthrinse with chlorhexidine gluconate at the clinical and patient level. Journal of Indian Society of Periodontology 2011; 15(4); 349352.

[3.] Flotra L, Gjermo P, Rolla G, Waerhaug J. Side effects of chlorhexidine mouthwashes. Scandinavian Journal of Dental Research 1971; $79 ; 119-125$.

[4.] Needleman IG. A guide to systematic reviews. Journal of Clinical Periodontlogy 2002; 29(suppl.3); 6-9.

[5.] Pooja Agarwal, Nagesh L, Murlikrishnan. Evaluation of the antimicrobial activity of various concentrations of Tulsi (ocimum sanctum) extract against streptococcus mutans: An in vitro study. Indian Journal of Dental Research 2010; 21; 3357-359.

[6.] Dalirsani. Z, Aghazadeh. M, Amirchaghmaghi. M, Pakfetrat. A. In vitro comparison of the antimicrobial activity of ten herbal extracts against streptococcus mutans with chlorhexidine. Journal of Applied sciences 2011; 11(5); 878-882.

[7.] Vijaya Hegde, Vasavi. A study to assess the antibacterial effect of Triphala churna against streptococcus mutans-an in vitro study. Journal of Postgraduate Dentistry 2011; 1(2); 13-14.

[8.] Mansour Amin, Maryam Kazemi, Neda Rasaie. In Vitro Comparison of the Effects of Garlic Juice and Chlorhexidine Mouthwash on oral pathogen. Jundishapur Journal of Microbiology 2012; 1(1).

[9.] Fereshteh Sedighinia, Akbar Safipour Afshar, Saman soleimanpour, Reza zarif, Javad Asili, Kiarash Ghazvini. Antibacterial activity of Glycyrrhiza glabra against oral pathogens: an in vitro study. Avicenna Journal of Phytomedicine 2012; 2(3); 118-124.

[10.] Hasanali Shafiee, Hamed Mortazavi, Maryam Baharvand, Guita Eslami, Sedigheh Bakhtiari, Soodabeh Taheri, Fatemeh Namazi, Amin Asgari and Somayyeh Azimi . Iranian traditional medicine: Comparison of the antibacterial effect of ANNAS $0.2 \%$ and chlorhexidine 0.2\%. African Journal of Microbiology Research 2012; 6(15), 3600-3603. 